\section{Pengaruh 4P In Marketing Terhadap Kepuasan Konsumen Toko King Kosmetik Palembang}

\author{
Dessy Hershanty \\ Sekolah Tinggi Ilmu Ekonomi APRIN \\ Email: dessy.hershanty@gmail.com
}

\begin{abstract}
ABSTRAK
Penelitian ini bertujuan: (1) Untuk mengetahui pengaruh bauran pemasaran yang meliputi produk, tempat, promosi, dan harga terhadap kepuasan pelanggan toko King Kosmetik Palembang. (2) Untuk mengetahui sejauh mana pengaruh bauran pemasaran terhadap kepuasan pelanggan dalam pemakaian ulang, dan penolakan terhadap produk lain di toko King Kosmetik Palembang. Hasil penelitian menunjukkan bahwa Variabel bauran pemasaran (X) mempunyai peran yang signifikan terhadap kepuasan pelanggan di toko King Kosmetik Palembang. Terlihat t hitung $(0,460)>t$ tabel $(1,6736)$ yang berarti bauran pemasaran mempunyai andil dalam mempengaruhi kepuasan pelanggan pada toko King Kosmetik Palembang. Terlihat $F$ hitung sebesar 6,212 dengan nilai signifikansi 0,047, karena nilai signifikan lebih kecil dari 0,05, yang bauran pemasaran mempunyai andil dalam mempengaruhi kepuasan pelanggan pada toko King Kosmetik Palembang. Jika diantara produk, harga, lokasi, dan promosi yang paling berpengaruh terhadap kepuasan pelanggan adalah bagian produk.
\end{abstract}

Kata Kunci: bauran pemasaran, kepuasan konsumen

\section{PENDAHULUAN}

Persaingan yang semakin ketat dimana semakin banyak produsen yang terlibat dalam pemenuhan kebutuhan dan keinginan konsumen, menyebabkan setiap perusahaan harus menempatkan orientasi pada kepuasan konsumen sebagai tujuan utama. Dengan semakin banyaknya produsen yang menawarkan produk dan jasa, maka konsumen memiliki pilihan yang semakin banyak untuk menentukan jadi tidaknya pembelian.

Dalam perjalanannya kosmetik atau toko perlengkapan tata rias dan penampilan manusia semakin meningkat baik dalam jumlah maupun pelayanan yang diberikan. Keadaan tersebut menyebabkan adanya persaingan dengan toko perlengkapan tata rias lainnya. Akibatnya, mau tidak mau para pengusaha bisnis kosmetik tidak mempunyai pilihan lain kecuali memenangkan persaingan. Berkaitan dengan konsep pemasaran yang berorientasi pada konsumen maka manajemen dapat memberikan kepuasan pada konsumen dengan cara memenuhi kebutuhan dan keinginan yang diinginkan oleh konsumen tersebut. Dalam hubungan dengan perekonomian dan perkembangan perlengkapan kosmetik, King Kosmetik merupakan salah satu dari perdagangan produk kosmetik di kota Palembang.

King Kosmetik adalah sebuah toko yang menyediakan produk dan perlengkapan kosmetik untuk penampilan yang berlokasi di Jl. Angkatan 45 No.33 Palembang. King Kosmetik mempunyai banyak pelanggan karena secara umum pola pemasaran King Kosmetik lebih menekankan kepada kalangan menengah ke atas. Sehingga melihat pelanggan dari karakteristik itu baik dari asal domisilinya, tingkat pendapatannya, golongan usianya, dan jenis kelaminnya, diharapkan dapat memberikan gambaran
Submitted: SEPTEMBER 2020

Accepted: NOVEMBER 2020

\title{
JIMKES
}

Jurnal Ilmiah Manajemen Kesatuan Vol. 8 No. 3, 2020 pp. $305-316$ IBI Kesatuan
ISSN 2337-7860 ISSN $2337-7860$
E-ISSN $2721-169 \mathrm{X}$ 
Marketing Mix and tentang pendapat mengenai kepuasan pelanggan terhadap produk kosmetik yang Consumer ditawarkan.

Satisfaction

Tabel 1. Data Penjualan Happy Kosmetik

\begin{tabular}{|l|l|l|}
\hline Omset Penjualan Tahun & Pelanggan/bulan & Volum Penjualan/bulan \\
\hline 2016 & 100 & $2.150 .000 /$ bulan \\
\hline 2017 & 120 & $2.345 .000 /$ bulan \\
\hline 2018 & 110 & $2.250 .000 /$ bulan \\
\hline 2019 & 150 & $2.580 .000 /$ bulan \\
\hline
\end{tabular}

Kepuasan pelanggan merupakan hal yang sangat penting kaitannya dengan pengembangan usaha. Pelanggan yang mempunyai loyalitas yang tinggi akan senantiasa menggunakan produk atau jasa yang disediakan perusahaan, dan tidak akan terpengaruh jasa yang ditawarkan pihak lain. Kepuasan pelanggan juga dipengaruhi oleh kualitas pelayanan. Kualitas pelayanan sangat penting kaitannya dengan eksistensi dan perkembangan keberhasilan perusahaan jasa. Kualitas pelayanan akan berpengaruh pada kepuasan pelanggan yang pada akhirnya akan berdampak pada loyalitas pelanggan pada penyedia jasa tersebut.

Kembali ke masalah kepuasan pelanggan yang cukup unik untuk dapat diperkirakan, maka kita akan membahasnya melalui sudut pandang manajemen pemasaran dalam membentuk suatu perusahaan dengan pendekatam atribut pemasaran yaitu pada model bauran pemasaran. Marketing mix yang dikembangkan oleh Kotler Philip, terdiri dari product, promotion, price, dan place. Hal ini untuk melihat yang dirasakan pelanggan tentang kualitas produk atau jasa layanan perusahaan produk busana muslim dan kualitas produk atau jasa layanan seperti apa yang diinginkan oleh pelanggan.

Untuk mengidentifikasi pemenuhan tingkat kualitas harapan para konsumen tidak mudah, karena sekali konsumen dapat merasakan kualitas produk atau jasa layanan yang tinggi baik dari perusahaan maupun dari pesaingnya, maka mereka akan mengharapkan pengalaman yang sama akan berulang. Apabila suatu perusahaan dapat mengidentifikasi kualitas produk atau jasa layanan sesuai harapan konsumennya, dengan kata lain penawaran kualitas produk atau layanan jasa yang baik dapat mempengaruhi pemakaian ulang produk maupun jasa perusahaan. Kualitas produk atau jasa layanan yang baik dalam menciptakan kepuasan konsumen memberikan berbagai manfaat, diantaranya memberikan dasar yang kuat sehingga terciptanya kesetiaan konsumen yang pada akhirnya disebut sebagai loyalitas pelanggan.kepuasan pada suatu perusahaan akan menghalangi pelanggan agar tidak terpengaruh dari perusahaan lain (retention). Disamping itu, memiliki kepuasan yang tinggi juga menjadi pendorong untuk melakukan pembelian ulang (repurchase) serta mengajak orang lain untuk menggunakan jasa tersebut (referral).

Hal menarik lainnya tentang produk kosmetik ini adalah mengenai hal apa yang membuat orang mau melakukan kunjungan atau bahkan pembelian produk. Apakah karena faktor produk yang ditawarkan memiliki variasai produk yang banyak? Atau karena harga produk yang ditawarkan relatif terjangkau? Atau tempat penjualan dimana terdapat korelasi antara kenyamanan dengan berbelanja? Atau hanya sebuah trend untuk mengunjungi dan melakukan pembelian produk busana muslim?. Melalui survei awal yang peneliti lakukan di salah satu toko kosmetik ada yang belum menggunakan bauran pemasaran (marketing mix). Diantaranya ada yang lokasinya kurang strategis, harga terlalu tinggi dan tidak bisa dijangkau kalangan menengah kebawah, padahal apabila harga dan tempat kurang strategis dapat mempengaruhi loyalitas pembeli untuk melakukan pembelian, dan ada juga yang tidak melakukan promosi tetapi tempat tersebut banyak pelanggannya.

Oleh karena itu penulis memandang perlu diadakan penelitian tentang $4 \mathrm{P}$ in Marketing atau bauran pemasaran terhadap kepuasan pelanggan pada King Kosmetik Palembang. Agar dapat memperoleh informasi yang lebih jelas dan disertai bukti ilmiah mengenai bagaimana pengaruh penerapan bauran pemasaran produk kosmetik terhadap pembentukan perasaan puas bagi pelanggan, maka perlu diadakan suatu penelitian 
ilmiah. Untuk itu penulis akan melakukan penelitian dengan menjadikan toko King Kosmetik Palembang sebagai tempat penelitian yang akan dikaji.

Penelitian ini bertujuan:

Marketing Mix and

Consumer

Satisfaction

1. Untuk mengetahui pengaruh bauran pemasaran yang meliputi produk, tempat, promosi, dan harga terhadap kepuasan pelanggan toko King Kosmetik Palembang.

2. Untuk mengetahui sejauh mana pengaruh bauran pemasaran terhadap kepuasan pelanggan dalam pemakaian ulang, dan penolakan terhadap produk lain di toko King Kosmetik Palembang

\section{METODE PENELITIAN}

Data yang digunakan dalam penelitian ini adalah data kuantitatif. Dalam penelitian ada dua jenis data, yaitu data primer dan data sekunder. Sumber data primer yaitu data yang diperoleh langsung dari sumber pertama. Sumber data yang penulis gunakan dalam penelitian ini adalah data yang diperoleh dengan cara wawancara secara langsung dengan karyawan, atau manajer Toko King Kosmetik yang terkait, serta penulis melakukan transaksi secar langsung guna memperoleh data yang akurat. Sumber data sekunder adalah sumber yang dapat memberikan informasi atau data tambahan yang dapat memperkuat data pokok, baik yang berupa manusia atau benda (majalah, buku, Koran, dl1). Sampel Penelitian ini adalah sebanyak 55 orang responden yang merupakan konsumen produk Kosmetik

Berbagai data yang dikumpulkan dalam penelitian ini dilakukan dengan berbagai metode, yaitu: 1. Metode Interview (wawancara), yaitu Metode pengumpulan data dengan cara melakukan tanya jawab secara lisan kepada pelanggan toko King Kosmetik Palembang. 2. Metode Kuesioner (angket), yaitu dengan memberikan daftar pertanyaan yang telah dibuat dan ditentukan urutan serta formatnya olaeh peneliti kepada responden, yaitu seluruh pelanggan toko King Kosmetik Palembang. 3. Metode Studi Pustaka, Di dalam pengumpulan data study pustaka penulis memperoleh data-data dari buku, serta bacaan-bacaan lain yang berhubungan dengan judul penelitian. Data dianalisis menggunakan metode analisis regresi linier sederhana. Uji validitas, uji reliabilitas dan uji asumsi klasik dilakukan untuk mengukur kualitas data penelitian.

Berdasarkan pada kajian teori dan perumusan masalah, serta kerangka berpikir tersebut diatas, maka hipotesis yang diajukan adalah: "Ada pengaruh Positif 4P In Marketing Terhadap Kepuasan Pelanggan toko King Kosmetik Palembang"

\section{HASIL DAN PEMBAHASAN \\ Gambaran Umum Obyek Penelitian}

Sejarah berdirinya toko King Kosmetik Palembang tak lepas dari kondisi dan situasi pasar produk kosmetik yang belum ada toko khusus produk beserta perlengkapan kosmetik lainnya secara lengkap. Toko King Kosmetik beridiri sejak tahun 2014 beralamat di Jalan Angkatan 45 No.33 Lorok Pakjo Ilir Barat I Palembang. Adapun tujuan didirikannya toko King Kosmetik Palembang adalah untuk memenuhi ragam kebutuhan dan perlengkapan kosmetik terutama untuk kaum wanita. Sebagai konsistensinya untuk menjadi bagian dari gaya hidup konsumen. Toko King Kosmetik Palembang memberikan pilihan bagi konsumen produk kosmetik mereka.

Sebagai bagian dari komitmen perusahaan dalam mendukung penungkatan ekonomi nasional, toko King Kosmetik Palembang memberikan fokus dan perhatian terhadap eksistensi dan daya saing produk lokal sebagai dukungan terhadap pemerintah dalam membatasi produk impor. Dengan kontribusi $80 \%$ produk lokal, toko King Kosmetik Palembang berharap dapat turut berkontribusi bagi industri lokal untuk dapat diakses dimana pun berada.

Bauran Pemasaran di Toko King Kosmetik Palembang

1. Analisis produk 
Marketing Mix and Consumer Satisfaction

308
Toko King Kosmetik Palembang menyediakan produk dan perlengkapan kosmetik mulai dari pria dan wanita. Selain itu, toko ini juga menyediakan alat-alat kebutuhan untuk kecantikan dan kebutuhan tubuh lainnya.

2. Analisis harga

Banyak sekali masyarakat kalangan menengah kebawah datang untuk membeli produk kosmetik di toko ini. Karena harga yang ditawarkan oleh toko ini relative murah. Jadi pas untuk kalangan menengah ke bawah.

3. Analisis tempat

Toko King Kosmetik Palembang terletak di pinggir jalan Angkatan 45 No.33 Palembang yang berarti toko ini berada di jalan utama antar kota. Tak heran banyak sekali pengunjung yang hanya sekedar mampir untuk melihat karena tempatnya yang mudah dijangkau oleh kendaraan umum.

4. Analisis iklan

Iklan dilakukan cukup dengan memasang papan nama dipinggir jalan serta menyebarkan brosur-brosur yang ada di Toko King Kosmetik Palembang, hal ini dirasa penting untuk memberitahukan kepada masyarakat umum tentang produk yang disediakan toko ini.

\section{Karakteristik Responden}

Sebelum dilakukan analisis, terlebih dahulu penulis akan menjelaskan mengenai datadata responden yang digunakan sebagai sampel yang diambil responden pelanggan pada King Kosmetik berikut ini:

Tabel 2 Deskriptif Statistik Responden

\begin{tabular}{|l|c|l|l|l|l|l|l|l|l|}
\hline Karakteristik & $\mathbf{N}$ & $\mathbf{M i n}$ & $\mathbf{M a x}$ & Mean & $\begin{array}{c}\text { Std } \\
\text { Dev }\end{array}$ & \multicolumn{2}{|c|}{ Skewness } & \multicolumn{2}{|c|}{ Kurtosis } \\
\hline $\begin{array}{l}\text { Jenis } \\
\text { Kelamin }\end{array}$ & 55 & 1 & 2 & 1.69 & .466 & -.850 & .322 & -1.328 & .634 \\
\hline Pekerjaan & 55 & 1 & 4 & 2.27 & 1.269 & .478 & .322 & -1.093 & .634 \\
\hline usia & 55 & 1 & 5 & 2.62 & 1.163 & .363 & .322 & -.576 & .634 \\
\hline pend & 55 & 1 & 4 & 3.07 & .879 & -.655 & .322 & -.281 & .634 \\
\hline
\end{tabular}

Sumber Data Primer Diolah

Berdasarkan data di atas bahwa pengaruh bauran pemasaran terhadap kepuasan pelanggan dapat di ketahui tentang jenis kelamin responden pelanggan di toko King Kosmetik yangg diambil sebagai responden, yang menunjukan bahwa mayoritas responden adalah wanita ( $\max$ statistic menunjukan angka $2=$ wanita). Hal ini menunjukan bahwa sebagian besar dari responden pelanggan pada toko King Kosmetik yang diambil sebagai responden adalah perempuan. Dan nilai skewness dan kurtosis masing-masing menunjukan -0.850 dan -1.328 . sehingga dapat disimpulkan bahwa data responden berdasarkan jenis kelamin terdistribusi secara normal.

Pekerjaan responden pelanggan di toko King Kosmetik Palembang yang diambil sebagai responden, yang menunjukan bahwa mayoritas pekerjaan responden adalah pegawai swasta ( $\max$ statistic menunjukan angka $5=$ pegawai swasta). Hal ini menunjukan bahwa sebagian besar dari responden pelanggan pada pengaruh bauran pemasaran terhadap kepuasan pelanggan yang diambil sebagai responden adalah pegawai swasta. Dan nilai skewness dan kurtosis masing-masing menunjukan 0.478 dan -1.093. sehingga dapat disimpulkan bahwa data responden berdasarkan pekerjaan terdistribusi secara normal.

Berdasarkan data di atas bahwa peran bauran pemasaran terhadap kepuasan pelanggan dapat di ketahui tentang usia responden pelanggan toko King Kosmetik Palembang yang diambil sebagai responden, yang menunjukan bahwa mayoritas responden adalah berusia +51 ( $\max$ statistic menunjukan angka $5=+51$ ). Hal ini menunjukan bahwa sebagian besar dari responden pelanggan pada pengaruh bauran pemasaran terhadap kepuasan pelanggan yang diambil sebagai responden adalah berusia +51. Dan nilai skewness dan kurtosis masing-masing menunjukan 0.363 dan -0.576 . 
sehingga dapat disimpulkan bahwa data responden berdasarkan usia terdistribusi secara normal.

Berdasarkan data di atas bahwa peran bauran pemasaran terhadap kepuasan pelanggan dapat di ketahui tentang pendidikan responden pelanggan toko King Kosmetik Palembang yang diambil sebagai responden, yang menunjukan bahwa mayoritas responden adalah perguruan tinggi (max statistic menunjukan angka $4=$ perguruan tinggi). Hal ini menunjukan bahwa sebagian besar dari responden pelanggan pada peran bauran pemasaran terhadap kepuasan pelanggan yang diambil sebagai responden adalah perguruan tinggi. Dan nilai skewness dan kurtosis masing-masing menunjukan -0.655 dan -0.281 sehingga dapat disimpulkan bahwa data responden berdasarkan pendidikan terdistribusi secara normal.

\section{Deskripsi Data Penelitian \\ Bauran Pemasaran}

Hasil analisis menunjukkan bahwa untuk variabel bauran pemasaran, Item 1, 75\% responden menyatakan sangat setuju bahwa pelanggan mengharapkan kualitas produk yang disediakan oleh toko King Kosmetik berkualitas, sedangkan sebanyak $25 \%$ memilih setuju. Pada item pertanyaan 2, $65 \%$ responden menyatakan sangat setuju bahwa pelanggan mengharapkan produk kosmetik berkualitas dan original, sedangkan sebanyak $\%$ menyatakan setuju. Pada item 3, 60 \% responden menyatakan setuju bahwa pelanggan mengaharapkan produk kosmetik mempunyai tersedia banyak, sedangkan sisanya sebanyak $40 \%$ menyatakan sangat setuju. Pada item pertanyaan 4, $53 \%$ responden menyatakan setuju bahwa pelanggan mengharapkan produk kosmetik dikemas dengan menarik, sedangkan sisanya sebanyak $47 \%$ menyatakan sangat setuju. Pada item pertanyaan $5,78 \%$ responden menyatakan setuju bahwa pelanggan mengharapkan harga produk busana muslim dijual dengan harga murah, sedangkan begitu pula sebanyak 22 $\%$ menyatakan sangat setuju. Pada item pertanyaan $6,50 \%$ responden menyatakan setuju bahwa pelanggan mengharapkan produk busana muslim sama dengan yang ada dipasaran, sedangkan begitu pula sebanyak $50 \%$ menyatakan sangat setuju .

Pada item pertanyaan 7, $63 \%$ responden menyatakan setuju bahwa pelanggan mengharapkan harga dari produk kosmetik ada diskon disetiap pembelian karena anda adalah pelanggan tetap, sedangkan begitu pula sebanyak $37 \%$ menyatakan sangat setuju. Pada item pertanyaan 8, $62 \%$ responden menyatakan setuju bahwa pelanggan mengharapkan ada diskon di setiap bulannya, sedangkan begitu pula sebanyak $38 \%$ menyatakan sangat setuju. Pada item pertanyaan 9, $71 \%$ responden menyatakan setuju bahwa pelanggan mengharapkan harga produk kosmetik dapat dijangkau oleh kalangan menengah kebawah, sedangkan begitu pula sebanyak $29 \%$ menyatakan sangat setuju. Pada item pertanyaan 10,67\% responden menyatakan setuju bahwa pelanggan mengharapkan lingkungan toko bersih, sedangkan begitu pula sebanyak $33 \%$ menyatakan sangat setuju. Pada item pertanyaan $11,77 \%$ responden menyatakan setuju bahwa pelanggan mengharapkan harga produk kosmetik dapat dijangkau oleh kalangan menengah kebawah, sedangkan begitu pula sebanyak $33 \%$ menyatakan sangat setuju.

Pada item pertanyaan $12, \%$ responden menyatakan setuju bahwa pelanggan mengharapkan toko King Kosmetik memiliki parkir kendaraan sendiri, sedangkan begitu pula sebanyak \% menyatakan sangat setuju. Pada item pertanyaan $13, \%$ responden menyatakan setuju bahwa pelanggan mengharapkan toko King Kosmetik mudah dijangkau oleh kendaraan umum, sedangkan begitu pula sebanyak \% menyatakan sangat setuju. Pada item pertanyaan $14,24 \%$ responden menyatakan setuju bahwa pelanggan mengharapkan lingkungan toko King Kosmetik terasa nyaman, sedangkan begitu pula sebanyak $76 \%$ menyatakan sangat setuju. Pada item pertanyaan 15, 66 \% responden menyatakan setuju bahwa pelanggan mengharapkan iklan produk kosmetik dikemas sermenarik mungkin, sedangkan begitu pula sebanyak $50 \%$ menyatakan sangat setuju. Pada item pertanyaan 16, $66 \%$ responden menyatakan setuju bahwa pelanggan mengharapkan iklan produk kosmetik dibuat sesuai dengan barang, sedangkan begitu pula sebanyak $44 \%$ menyatakan sangat setuju. Pada item pertanyaan $17,55 \%$ responden 
Marketing Mix and Consumer Satisfaction

310 menyatakan setuju bahwa pelanggan mengharapkan iklan produk kosmetik diiklankan menggunakan brosur, sedangkan begitu pula sebanyak $45 \%$ menyatakan sangat setuju. Pada item pertanyaan 18, $60 \%$ responden menyatakan setuju bahwa pelanggan mengharapkan agar ditiap promosi produk baru dengan memberikan diskon, sedangkan begitu pula sebanyak $40 \%$ menyatakan sangat setuju.

\section{Kepuasan Pelanggan}

Untuk variabel kepuasan pelanggan, item pertanyaan 19,41 \% responden menyatakan setuju bahwa pelanggan mengharapkan agar pelanggan senang dan terus menggunakan produk dari anda, sedangkan begitu pula sebanyak $59 \%$ menyatakan sangat setuju. Pada item pertanyaan $20,49 \%$ responden menyatakan setuju bahwa pelanggan mengharapkan agar selalu melakukan pembelian ulang ditoko ini, sedangkan begitu pula sebanyak $51 \%$ menyatakan sangat setuju. Pada item pertanyaan $21,60 \%$ responden menyatakan setuju bahwa pelanggan mengharapkan agar bersedia membeli produk lain ditoko yang sama, sedangkan begitu pula sebanyak $40 \%$ menyatakan sangat setuju. Pada item pertanyaan $22,40 \%$ responden menyatakan setuju bahwa pelanggan mengharapkan agar bersedia membeli produk yang sama ditoko yang lain, sedangkan begitu pula sebanyak $60 \%$ menyatakan sangat setuju. Pada item pertanyaan $23,56 \%$ responden menyatakan setuju bahwa pelanggan mengharapkan agar pelanggan senang dengan produk, harga, lokasi, dan promosi yang ditawarkan, sedangkan begitu pula sebanyak $34 \%$ menyatakan sangat setuju. Pada item pertanyaan $24,40 \%$ responden menyatakan setuju bahwa pelanggan mengharapkan pelanggan senag dengan pelayanan yang ada, sedangkan begitu pula sebanyak $60 \%$ menyatakan sangat setuju.

\section{Uji Validasi dan Reliabilitas Instrumen}

Tabel 3 Hasil Uji Validitas Instrumen

\begin{tabular}{|c|c|c|c|c|}
\hline Variabel & $\begin{array}{l}\text { Item } \\
\text { pertayaan }\end{array}$ & $\begin{array}{l}\text { I } \\
\text { hitung }\end{array}$ & I tabel & Kesimpulan \\
\hline \multirow[b]{18}{*}{ Bauran $(\mathrm{X})$} & pertayaan 1 & 0,356 & 0,266 & Valid \\
\hline & pertayaan 2 & 0,567 & 0,266 & Valid \\
\hline & pertayaan 3 & 0,267 & 0,266 & Valid \\
\hline & pertayaan 4 & 0,401 & 0,266 & Valid \\
\hline & pertayaan 5 & 0,880 & 0,266 & Valid \\
\hline & pertayaan 6 & 0.932 & 0.266 & Valid \\
\hline & pertayaan 7 & 0,277 & 0,266 & Valid \\
\hline & pertayaan 8 & 0,683 & 0,266 & Valid \\
\hline & pertayaan 9 & 0,931 & 0,266 & Valid \\
\hline & pertayaan 10 & 0,707 & 0,266 & Valid \\
\hline & pertayaan 11 & 0,383 & 0,266 & Valid \\
\hline & pertayaan 12 & 0,267 & 0,266 & Valid \\
\hline & pertayaan 13 & 0,474 & 0,266 & Valid \\
\hline & pertayaan 14 & 0,280 & 0,266 & Valid \\
\hline & pertayaan 15 & 0,406 & 0,266 & Valid \\
\hline & pertayaan 16 & 0,600 & 0,266 & Valid \\
\hline & pertayaan 17 & 0,674 & 0,266 & Valid \\
\hline & pertayaan 18 & 0,492 & 0,266 & Valid \\
\hline \multirow{5}{*}{$\begin{array}{l}\text { KEPUASAN } \\
\text { PELANGGAN }\end{array}$} & pertayaan 19 & 0,309 & 0,266 & Valid \\
\hline & pertayaan 20 & 0,994 & 0,266 & Valid \\
\hline & pertayaan 21 & 0,344 & 0,266 & Valid \\
\hline & pertayaan 22 & 0,544 & 0,266 & Valid \\
\hline & pertayaan 23 & 0,491 & 0,266 & Valid \\
\hline
\end{tabular}

Sumber : Data Primer yang diolah 2012

Untuk menguji validitas dan reabilitas instrument, penulis menggunakan analisis dengan SPSS. Berikut hasil pengujian validitas. Uji validitas digunakan untuk menunjukkan sejauh mana ketepatan dan kecermatan suatu alat ukur (kuesioner). Uji 
validitas dalam penelitian ini dihitung dengan menggunakan SPSS Versi 22. Untuk tingkat validitas dilakukan uji signifikasi dengan membandingkan nilai $r$ hitung dengan nilai $\mathrm{r}$ tabel. Untuk degree of freedo $(\mathrm{df})=\mathrm{n}-\mathrm{k}$ dalam hal ini $\mathrm{n}$ adalah jumlah sampel dan $\mathrm{k}$ adalah jumlah konstruk. Pada kasus ini besarnya df dapat dihitung 100-2 atau df 98 dengan alpha 0,05 didapat $r$ table 0,197 , jika $r$ hitung (untuk tiap-tiap butir pertanyaan dapat dilihat pada kolom corrected item pertanyaan total correlation) lebih besar dari $r$ table dan nilai positif, maka butir pertanyaan tersebut dinyatakan valid. Pengujian validitas dalam penelitian ini dihitung dengan menggunakan bantuan computer program SPSS sebagaimana Tabel 3. Dari tabel tersebut diatas dapat diketahui bahwa masingmasing item pertayaan memiliki $r$ hitung $>$ dari $r$ tabel $(0,266)$ dan bernilai positif. Maka dengan demikian butir pertayaan tersebut valid.

Table 4. Hasil Uji Reliabilitas Instrumen Variabel

\begin{tabular}{|l|l|l|l|}
\hline Variabel & Indikator & Cronbach Alpha & Keterangan \\
\hline Produk & pertayaan 1 & 0,605 & Reliabel \\
\hline & pertayaan 2 & 0,621 & Reliabel \\
\hline & pertayaan 3 & 0,629 & Reliabel \\
\hline & pertayaan 4 & 0,629 & Reliabel \\
\hline Price & pertayaan 5 & 0,609 & Reliabel \\
\hline & pertayaan 6 & 0,640 & Reliabel \\
\hline & pertayaan 7 & 0,614 & Reliabel \\
\hline & pertayaan 8 & 0,635 & Reliabel \\
\hline Place & pertayaan 9 & 0,643 & Reliabel \\
\hline & pertayaan 10 & 0,650 & Reliabel \\
\hline & pertayaan 11 & 0,666 & Reliabel \\
\hline & pertayaan 12 & 0,612 & Reliabel \\
\hline & pertayaan 13 & 0,632 & Reliabel \\
\hline Promotion & pertayaan 14 & 0,622 & Reliabel \\
\hline & pertayaan 15 & 0,615 & Reliabel \\
\hline & pertayaan 16 & 0,633 & Reliabel \\
\hline & pertayaan 17 & 0,657 & Reliabel \\
\hline Kepusaan & pertayaan 18 & 0,634 & Reliabel \\
\hline \multirow{2}{*}{ pelanggan } & pertayaan 19 & 0,617 & Reliabel \\
\cline { 2 - 4 } & pertayaan 20 & 0,659 & Reliabel \\
\cline { 2 - 4 } & pertayaan 21 & 0,670 & Reliabel \\
\hline & pertayaan 22 & 0,651 & Reliabel \\
\hline & pertayaan 23 & 0,643 & Reliabel \\
\hline
\end{tabular}

Sumber: Data Primer yang Diolah

Dari keterangan tabel di atas dapat diketahui masing-masing item pertayaan memiliki Cronbach Alpha > 0,60 . maka variabel independen (bauran pemasaran) dan variabel dependen (kepusan pelanggan) dapat dikatakan reliable.

\section{Uji Asumsi Klasik}

Berdasarkan hasil pengujian segala penyimpangan klasik terhadap data penelitian dapat dijelaskan sebagai berikut:

Uji multikolinearitas bertujuan untuk menguji apakah dalam suatu model regresi ditemukan adanya korelasi antar variabel independent dalam suatu model regresi. Model regresi yang baik tidak terjadi korelasi diantara variabel independen.

\section{Tabel 5. Hasil Uji Multikolinieritas}

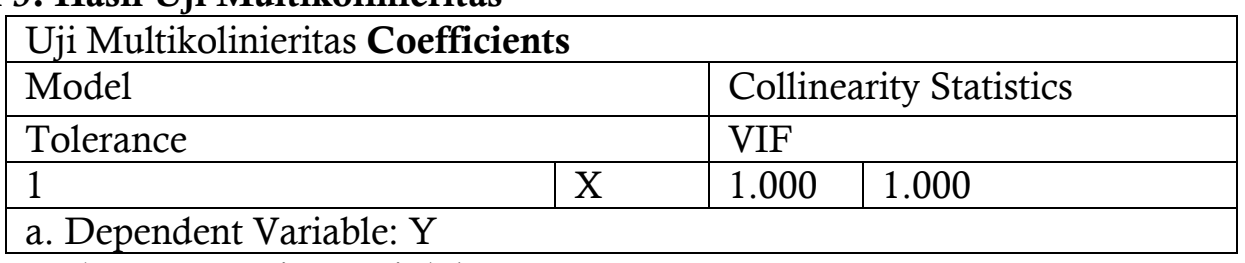

Sumber: Data Primer Diolah
Marketing Mix and Consumer Satisfaction 
Marketing Mix and Consumer Satisfaction

312
Dari hasil pengujian multikolinearitas diketahui nilai toleransi kurang dari 0,1 yang berarti vaiabel independen (bauran pemasaran) tidak ada korelasi anrat variabel independen yang nilainya $95 \%$. Hasil perhitungan VIF untuk variabel bauran pemasaran jauh dari 10. Jadi dapat disimpulkan tidak ada multikolonieritas antar variabel independen dalam regresi.

Uji Autokorelasi dilakukan untuk menguji suatu model apakah antara variable pengganggu masing-masing variable bebas saling mempengaruhi. Adapun hasil pengujian autokorelasi adalah sebagai berikut:

Tabel 6. Hasil Uji Autokorelasi

\begin{tabular}{|c|c|l|l|l|l|}
\hline \multicolumn{6}{|l|}{ Uji Autokorelasi Model Summaryb } \\
\hline Model & $\mathrm{R}$ & $\mathrm{R}$ Square & $\begin{array}{c}\text { Adjusted R } \\
\text { Square }\end{array}$ & $\begin{array}{c}\text { Std. Error of the } \\
\text { Estimate }\end{array}$ & $\begin{array}{c}\text { Durbin- } \\
\text { Watson }\end{array}$ \\
\hline 1 & $.263 \mathrm{a}$ & .054 & .065 & 3.088 & 0.703 \\
\hline a. Predictors: (Constant), X
\end{tabular}

Sumber: Data Primer Diolah

Nilai DW sebesar 1,703 nilai ini akan dibandingkan dengan niali tabel dengan menggunakna nilai signifikan 5\%, jumlah smpel 55 (n) dan jumlah variabel independen $1(\mathrm{~K}=1)$, maka dalam tabel $\mathrm{DW}$ akan didapat $\mathrm{Dl}=1,528$ dan $\mathrm{Du}=1,601$. Berdasarkan tabel keputusan autokorelasi bisa diambil kesimpulan bahwa tidak ada autokorelasi positif.

Uji Heteroskedastisitas bertujuan untuk menguji apakah dalam model regresi terjadi katidaksamaan variant.49 Adapun hasil uji statistik Heterokedasias yang diperoleh dalam penelitian ini adalah sebagai berikut:

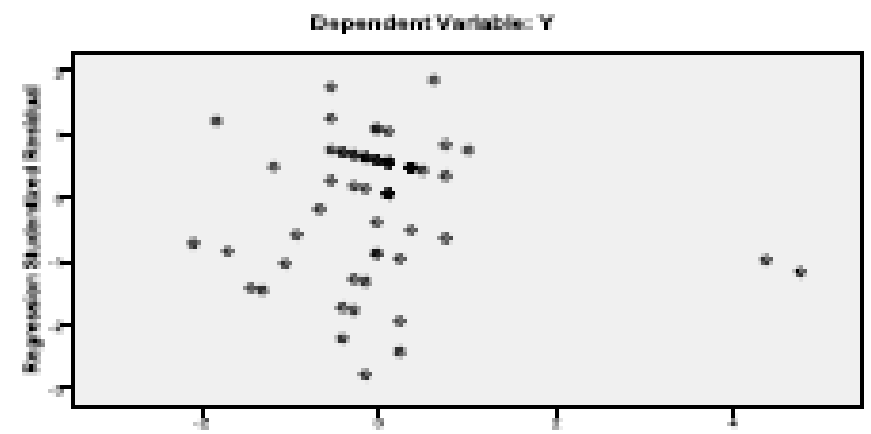

Gambar 1. Scatterplot Data

Berdasarkan grafik scatterplot menunjukan bahwa terdapat pola yang jelas serta titik yang menyebar diatas dan di bawah angka 0 padasumbu Y. jadi dapat disimpulakan bahwa tidak terjadi heteroskedastisitas dalam regresi

Uji normalitas bertujuan untuk menguji apakah dalam model regresi, variabel pengganggu atau residual memiliki distribusi normal. Uji normalitas dalam penelitian ini menggunakan analisis grafik.

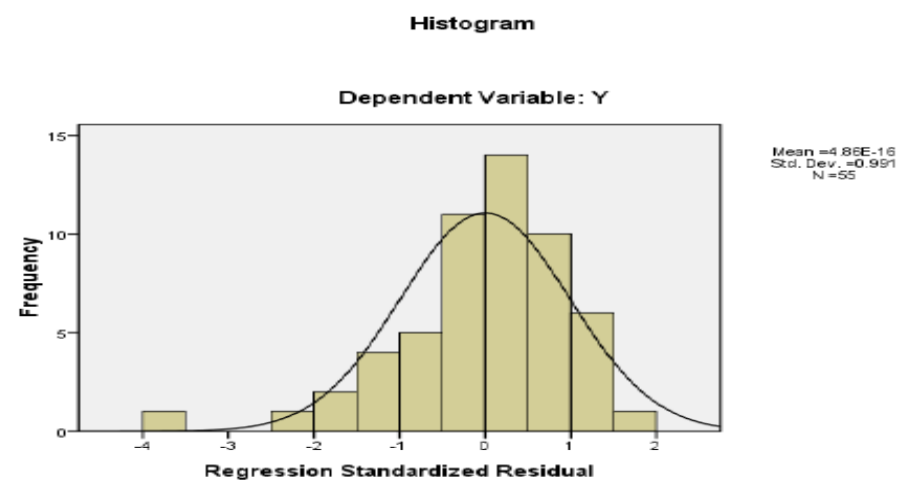

Gambar 2 Histogram Data

Dari grafik histrogram atau grafik normal plot dapat disimpulkan bahwa grafik histrogram memberikan pola distribusi ke kanan dan normal. Sedangkan pada grafik 
noramal plot terlihat bahwa menyebar disekitar garis diagonal serta seacara acak tersebar dibawah angka 0 pada sumbu y.

\section{Analisis Data}

Koefisien determinasi yang memiliki fungsi untuk menjelaskan sejauh mana kemampuan variabel independen (bauran pemasaran) terhadap variabel dependen (kepuasan pelanggan). Hasil olahan statistik yang dibantu program SPSS menunjukkan bahwa variabel independen hanya mampu menjelaskan variabel dependen sebesar 5,8\% sedang yang $94,2 \%$ sisanya dijelaskan variabel lain yang tidak dimasukkan dalam model ini. Koefisien determinasi dilakukan untuk mengethui seberapa besar nilai prosentase kontribusi variabel bauran pemasaran terhadap kepusan pelanggan. Dari hasil perhitrungan didapat nilai koefisien determinasi sebagai berikut:

Tabel 7 Koefisisen Determinasi

\begin{tabular}{|l|l|l|l|l|l|}
\hline Model & $\mathrm{R}$ & R Square & $\begin{array}{l}\text { Adjusted R } \\
\text { Square }\end{array}$ & $\begin{array}{l}\text { Std. Error of the } \\
\text { Estimate }\end{array}$ & $\begin{array}{l}\text { Durbin- } \\
\text { Watson }\end{array}$ \\
\hline 1 & $.263 \mathrm{a}$ & .054 & .065 & 3.088 & 0.703 \\
\hline
\end{tabular}

Dari tabel diatas ditunjukan dengan hasil perhitungan menghasilkan $\mathrm{F}$ hitung sebesar 6,212 dengan nilai signifikansi 0,047, karena nilai signifikan lebih kecil dari 0,05 maka Ha diterima dan menolak Ho. jadi dapat disimpulkan bahwa bauran pemasaran berpengaruh terhadap kepusan pelanggan. Dengan demikian, dapat disimpulkan bahwa hipotesis nol uang menyatakan "tidak ada pengaruh antara variabel bauran pemasaran denga kepuasan pelanggan" tidak sanggup diterima yang berarti menerima hipotesis alternative yang berbunyi "ada pengaruh antara variabel bauran pemasaran terhadap kepuasan pelanggan".

Tabel 8 Hasil Uji t

\begin{tabular}{|c|c|c|c|c|c|}
\hline \multirow[t]{2}{*}{ Model } & \multirow{2}{*}{$\begin{array}{l}\text { Unstandardized } \\
\text { Coefficients }\end{array}$} & \multicolumn{2}{|c|}{ Standardized Coefficients } & \multirow[t]{2}{*}{$\mathrm{t}$} & \multirow[t]{2}{*}{ Sig. } \\
\hline & & B & Std. Error & & \\
\hline 1 & (Constant) & 1.057 & 11.978 & 1.508 & .138 \\
\hline $\mathrm{X}$ & .566 & .144 & .063 & .460 & .047 \\
\hline
\end{tabular}

Dari tabel 8 diatas dapat diketahui bahwa hasil analisis regresi diperoleh koefisien untuk variabel sebesar 0,566 dengan nilai konstanta sebesar 1,057 sehingga persamaan regresi sebagai berikut: $\mathrm{Y}=1,057+0,566 \mathrm{X}$

Kepuasan Pelanggan $Y=1,057+0,566$ Bauran Pemasaran

Konstanta sebesar 1,057 menyatakan bahwa jika variabel independen dianggap konstan, maka variabel dependen sebesar 1,057 .

Kofisien regresi sebesar 0,566 menyatakan bahwa jika variabel independen (bauran pemasaran) naik 1\%, maka variabel dependen (kepuasan pelanggan) akan naik 56,6\%. Sebalikanya jika variabel independen (bauran pemasaran) turun $1 \%$, maka variabel dependen (kepuasan pelanggan) akan turun 56,6\%.

\section{Bauran Pemasaran Terhadap Kepuasan Pelanggan}

Hasil uji empiris pengaruh antara bauran pemasaran terhadap kepuasan pelanggan, menunjukkan nilai t hitung 0,46 dan p value (Sig) sebesar 0,47 yang dibawah alpha 5\%. Artinya bahwa bauran pemasaran terhadap kepuasan pelanggan. Hasil penelitian tidak dapat menolak hipotesis yang menyatakan "Variabel bauran pemasaran berpengaruh signifikan terhadap loyalitas pelanggan". Nilai beta adalah Understandardized Coefficients variabel bauran pemasaran menunjukkan angka sebesar 0,566 , yang artinya adalah besaran pengaruh bauran pemasaran terhadap kepuasan pelanggan adalah sebesar $56,6 \%$.

Koefisien regresi sebesar 0,566 Menyatakan bahwa setiap penambahan (karena memiliki tanda +) \% bauran pemasaran maka akan menambah kepuasan pelanggan sebesar \%, demikian pula jika terjadi sebaliknya. Hasil penelitian ini menunjukkan bahwa bauran pemasaran merupakan variabel bebas yang secara signifikan berpengaruh terhadap kepuasan pelanggan.

\section{Pembahasan}


Marketing Mix and Consumer Satisfaction
Pengaruh masing-masing variabel independen (bauran pemasaran) dan variabel dependen (kepuasan pelanggan) dapat dijelaskan sebagai berikut. Dari hasil pengujian yang dilakukan terbukti bahwa bauran pemasaran memiliki pengaruh yang signifikan terhadap kepuasan pelanggan pada toko King Kosmetik Palembang ( $\mathrm{P}$ value $<0.05)$. bauran pemasaran merupakan faktor yang perlu diperhitungkan dalam kepuasan pelanggan. Semakin baik bauran pemasaran yang diberikan, pelanggan akan semakin menunjukkan rasa puasnya kepada toko King Kosmetik Palembang. Dari hasil pengujian yang dilakukan terbukti bauran pemasaran memiliki pengaruh yang signifikan terhadap kepuasan pelanggan pada toko King Kosmetik Palembang. Ini ditunjukkan dengan hasil jawaban responden pada masing-masing item pertanyaan. Pada item $1,75 \%$ responden menyatakan sangat setuju bahwa pelanggan mengharapkan kualitas produk yang dikeluarkan oleh toko King Kosmetik Palembang, sedangkan sebanyak $25 \%$ memilih setuju. Pada ietem pertanyaan 2, $65 \%$ responden menyatakan sangat setuju bahwa pelanggan mengharapkan produk kosmetik bermacam-macam dan original, sedangkan sebanyak \% menyatakan setuju.

Pada item 3, $60 \%$ responden menyatakan setuju bahwa pelanggan mengaharapkan produk kosmetik mempunyai tersedia banyak, sedangkan sisanya sebanyak $40 \%$ menyatakan sangat setuju. Pada item pertanyaan 4, $53 \%$ responden menyatakan setuju bahwa pelanggan mengharapkan produk kosmetik dikemas dengan menarik, sedangkan sisanya sebanyak $47 \%$ menyatakan sangat setuju. Pada item pertanyaan 5, $78 \%$ responden menyatakan setuju bahwa pelanggan mengharapkan harga produk kosmetik dijual dengan harga murah, sedangkan begitu pula sebanyak $22 \%$ menyatakan sangat setuju. Pada item pertanyaan $6,50 \%$ responden menyatakan setuju bahwa pelanggan mengharapkan produk kosmetik sama dengan yang ada dipasaran, sedangkan begitu pula sebanyak $50 \%$ menyatakan sangat setuju .

Pada item pertanyaan 7, $63 \%$ responden menyatakan setuju bahwa pelanggan mengharapkan harga dari produk kosmetik ada diskon disetiap pembelian karena anda adalah pelanggan tetap, sedangkan begitu pula sebanyak $37 \%$ menyatakan sangat setuju. Pada item pertanyaan 8, $62 \%$ responden menyatakan setuju bahwa pelanggan mengharapkan ada diskon dsetiap bulannya, sedangkan begitu pula sebanyak $38 \%$ menyatakan sangat setuju. Pada item pertanyaan 9, $71 \%$ responden menyatakan setuju bahwa pelanggan mengharapkan harga produk busana kosmetik dapat dijangkau oleh kalangan menengah kebawah, sedangkan begitu pula sebanyak $29 \%$ menyatakan sangat setuju. Pada item pertanyaan 10,67\% responden menyatakan setuju bahwa pelanggan mengharapkan lingkungan toko bersih, sedangkan begitu pula sebanyak $33 \%$ menyatakan sangat setuju. Pada item pertanyaan $11,77 \%$ responden menyatakan setuju bahwa pelanggan mengharapkan harga produk kosmetik dapat dijangkau oleh kalangan menengah kebawah, sedangkan begitu pula sebanyak $33 \%$ menyatakan sangat setuju.

Pada item pertanyaan $12, \%$ responden menyatakan setuju bahwa pelanggan mengharapkan toko kosmetik memiliki parkir kendaraan sendiri, sedangkan begitu pula sebanyak \% menyatakan sangat setuju. Pada item pertanyaan 13, \% responden menyatakan setuju bahwa pelanggan mengharapkan toko kosmetik mudah dijangkau oleh kendaraan umum, sedangkan begitu pula sebanyak \% menyatakan sangat setuju. Pada item pertanyaan 14, $24 \%$ responden menyatakan setuju bahwa pelanggan mengharapkan lingkungan toko kosmetik terasa nyaman, sedangkan begitu pula sebanyak $76 \%$ menyatakan sangat setuju. Pada item pertanyaan 15, $66 \%$ responden menyatakan setuju. bahwa pelanggan mengharapkan iklan produk kosmetik dibuat sermenarik mungkin, sedangkan begitu pula sebanyak $50 \%$ menyatakan sangat setuju. Pada item pertanyaan 16, $66 \%$ responden menyatakan setuju bahwa pelanggan mengharapkan iklan produk busana muslim dibuat sesuai dengan barang, sedangkan begitu pula sebanyak $44 \%$ menyatakan sangat setuju. Pada item pertanyaan $17,55 \%$ responden menyatakan setuju bahwa pelanggan mengharapkan iklan busana muslim diklankan menggunakan brosur, sedangkan begitu pula sebanyak $45 \%$ menyatakan sangat setuju. 
Pada item pertanyaan 18,60\% responden menyatakan setuju bahwa pelanggan mengharapkan agar ditiap promosi produk baru dengan memberikan diskon, sedangkan begitu pula sebanyak $40 \%$ menyatakan sangat setuju.

Dari uraian diatas dapat diketahui bahwa pada variabel bauran pemasran masingmasing item pertanyaan sebagian besar dijawab setuju. Hal ini sejalan dengn pengujian hipotesa satu yang menyatakan bahwa ada pengaruh signifikan antara bauran produk dengan kepuasan pelanggan pada toko King Kosmetik Palembang yang ditunjukkan $\mathrm{P}$ value 0,047 yang lebih kecil dari signifikasi $5 \%$, sehingga pada akhirnya bauran produk mempunyai pengaruh yang signifikan terhadap kepuasan pelanggan pada toko King Kosmetik Palembang.

Dengan demikian dapat disimpulkan bahwa berdasarkan pengujian terhadap 55 responden pelanggan toko King Kosmetik Palembang adanya bukti untuk menolak Ho bahwa bauran produk tidak mempunyai pengaruh terhadap kepuasan pelanggan pada toko King Kosmetik Palembang dan menerima $\mathrm{Hl}$ bahwa ada pengaruh yang signifikan variabel bauran produk mempunyai pengaruh terhadap kepuasan pelanggan pada toko King Kosmetik Palembang.

Sedangkan hasil pengujian pengaruh variabel independen terhadap variabel dependen dapat dijelaskan oleh nilai $\mathrm{P}$ value sebesar 0,047 pada tabel anova, diman lebih kecil dari taraf signifikasi 0,5 , ini artinya variabel bauran pemasaran terhadap kepuasan pelanggan pada toko King Kosmetik Palembang dan ini sekaligus menjawab bahwa hipotesa dua $(\mathrm{H} 2)$ yang berbunyi secara terdapat pengaruh yang signifikan anatara bauran pemasaran berpengaruh terhadap kepuasan pelanggan pada toko King Kosmetik Palembang.

\section{PENUTUP}

Dengan melihat hasil penelitian yang telah dibahas, maka dapat ditarik kesimpulan:

1. Variabel bauran pemasaran (X) mempunyai peran yang signifikan terhadap kepuasan pelanggan di toko King Kosmetik Palembang. Terlihat $t$ hitung $(0,460)>t$ tabel $(1,6736)$ yang berarti bauran pemasaran mempunyai andil dalam mempengaruhi kepuasan pelanggan pada toko King Kosmetik Palembang. Terlihat F hitung sebesar 6,212 dengan nilai signifikansi 0,047, karena nilai signifikan lebih kecil dari 0,05, yang bauran pemasaran mempunyai andil dalam mempengaruhi kepuasan pelanggan pada toko King Kosmetik Palembang.

2. Jika diantara produk, harga, lokasi, dan promosi yang paling berpengaruh terhadap kepuasan pelanggan adalah bagian produk. .

\section{DAFTAR PUSTAKA}

[1] Amir, Taufik, 2015. Dinamika Pemasaran: Jelajahi dan Rasakan, Jakarta: Raja Grafindo Persada

[2] Arikunto, Suharsimi, 2008. Prosedur Penelitian Suatu Pendekatan Pendek, Jakarta: Rineka Cipta,

[3] Assauri, Sofjan, 2017. Manajemen Pemasaran, Jakarta: Raja Grafindo Persada,

[4] Amirullah, Imam Hardjanto, 2015. Pengantar Bisnis, Yogyakarta: Graha Ilmu,

[5] Fadillah, A., Sujana, S. and Sukartaatmadja, I., 2019. Kajian Minat Studi Lanjut Siswa-Siswi SMA dan SMK Kota Bogor Ke Perguruan Tinggi. JAS-PT (Jurnal Analisis Sistem Pendidikan Tinggi Indonesia), 3(1), pp.53-62.

[6] Hidayat, L., Muktiadji, N. and Supriadi, Y., 2019. Pengaruh Pengetahuan Investasi Terhadap Minat Mahasiswa Berinvestasi Di Galeri Investasi Perguruan Tinggi. JAS-PT (Jurnal Analisis Sistem Pendidikan Tinggi Indonesia), 3(2), pp.63-70.

[7] Kotler, Philip, A.B. Susnato, 2009. Hitt, Michael A., 2001. Manajemen Strategi: Daya Saing Dan Globalisasi; Konsep, Jakarta: Salemba Empat,

[8] Kotler, Philip, Gary Amstrong, 2007. Dasar-Dasar Pemasaran, Jakarta: Prehallindo,

[9] Longenecker, Justin G, 2011. Kewirausahaan: Manajemen Usaha Kecil, Jakarta: Salemba Empat,
Marketing Mix and Consumer Satisfaction 
Marketing Mix and Consumer Satisfaction

\section{6}

[10] Mulyana, M., Rainanto, B.H., Astrini, D. and Puspitasari, R., 2020. Persepsi Mahasiswa Atas Penggunaan Aplikasi Perkuliahan Daring Saat Wabah Covid19. JAS-PT (Jurnal Analisis Sistem Pendidikan Tinggi Indonesia), 4(1), pp.47-56.

[11] Nitisemito, Alex S, 2001. Marketing, Jakarta: Ghalia Indonesia,

[12] Nurendah, Y. and Rainanto, B.H., 2019, May. The Analysis of Shoes Marketing Mix in Style Successful Benefits SMEs of Shoes Product in Bogor. In 1st International Conference on Economics, Business, Entrepreneurship, and Finance (ICEBEF 2018). Atlantis Press.

[13] Prawira, Shafri Mangku, 2003Manajemen Sumber Daya Manusia Strategik, Jakarta: Ghalia Indonesia,

[14] Purba, J.H.V., 2017. The analysis of European Union's vegetable oil consumption:" will the European Parliament Resolution Halt the Consumption of Crude Palm Oil in the European Union in the future?". International Journal of Applied Business and Economic Research, 15, p.19.

[15] Purba, J.H.V. and Septian, M.R., 2019. Analysis of Short Term Financial Performance: A Case Study of an Energy Service Provider. Journal of Accounting Research, Organization and Economics, 2(2), pp.113-122.

[16] Putra, A.G. and Zuhdi, S., 2018. The Influence of Repositioning Strategies on Purchase Intention Through Brand Personality and Brand Association. In THE INTERNATIONAL CONFERENCE ON ACCOUNTING AND MANAGEMENT SCIENCE (p. 158).

[17] Sulistiono, S., Fadillah, A. and Putrie, D.E., 2020, May. Factors Affecting Bogor Botanical Garden Visitors' Intention Before and After the One Way System Application. In 2nd International Seminar on Business, Economics, Social Science and Technology (ISBEST 2019) (pp. 291-296). Atlantis Press.

[18] Zuhdi, S. and Yudi, D., 2008. ANALISIS BRAND LOYALTY TERHADAP KEPUTUSAN PEMBELIAN Studi Kasus Pengguna Mobil Merek TOYOTA Pada PT. Setiajaya Mobilindo Bogor. Jurnal Ilmiah Kesatuan Nomor, 10(97), p.2.

[19] Zuhdi, S., Daud, A., Hanif, R., Nguyen, P.T. and Shankar, K., 2019. Role of Social Media Marketing in the Successful Implementation of Business Management. International Journal of Recent Technology and Engineering, 8.

[20] Zuhdi, S., Rainanto, B.H. and Apriyani, D., 2020, May. Analysis of Co-Branding Strategy to Improve Company's Competitive Power (Case Study on Walls Selection Oreo). In 2nd International Seminar on Business, Economics, Social Science and Technology (ISBEST 2019) (pp. 146-149). Atlantis Press. 